Journal of Social and Development Sciences

Vol. 1, No. 3, pp. 91-100, Apr 2011

\title{
Constraints of Manufacture based Small and Medium Enterprise (SME) Development in Bangladesh
}

\author{
Feroz Ahmed ${ }^{1}, *$ Md. Mizanur Rahman¹, Monimul Haque ${ }^{2}$ \\ ${ }^{1}$ Business Administration Discipline, Khulna University, Bangladesh \\ 2Department of Finance and Banking, University of Rajshahi \\ *mizanurku03@yahoo.com
}

\begin{abstract}
Small and medium enterprises (henceforth, SMEs) play a key role in economic growth and industrial development of a country. They make vital contributions in improving economic and social sectors of a country through stimulating large scale employment, investment, development of indigenous skill and technology, promotion of entrepreneurship and innovativeness, enhancing exports, and also building an industrial base at different scales. SMEs worldwide have been benefited from the combined interactions of forces of product mix, location factors, and market advantages. However, evidences also suggest that there are cases of SME failures. Growth of SMEs is constrained by many factors. Many SMEs occasionally go on growing into large firms. This paper looks for identifying such constraints of manufacture based SME Development in Bangladesh. From the study, it has been identified that, lack of utility facilities, for example, electricity, gas and water, frequent changes of the prices of raw materials as well as shortage of raw materials, political unrest, high interest rate on borrowings, high transportation cost, lack of financing for ongoing concern, and inadequate infrastructure are the major constraints of manufacture based SMEs Development in Bangladesh. The researchers assume that few initiatives like developing necessary infrastructure, ensuring utility services, reducing bank rate and ensuring consistent supply of raw materials can change the total scenario and thus can help the manufacturing sector which in turn will result the industrial development of the country and thus will be able to contribute to the economic development.
\end{abstract}

Keywords: SMEs, economic growth, industrial development, innovativeness, constraints

\section{Introduction}

Bangladesh is a country where supply of raw materials, cheap labor and a large domestic market is abandon. Huge amount of raw materials and human resources can create a big market for the Small and Medium Enterprises (SMEs) in Bangladesh (Ahmed, 1987). Thus this sector has a big prospect (Sarder, 1990) and can contribute further to ensure sustainable growth of the economy. For the past few decades substantial interest has been developed regarding SMEs all over the world (Birch, 1979; Anderson, 1982; Gibb, 1993). Although the economic uniqueness of the small enterprises has been acknowledged globally, in Bangladesh this sector began to get some momentum during 1990s. Since then the government of Bangladesh started devising policy instruments to guard the sector from any sort of undue intervention. This shift in prioritization of different sectors of the economy by the government did not come all of a sudden, such a discernible move was rather imminent due to the facts that on the one hand agriculture sector, the mainstay of the economy, has long been suffering from low productivity problem and was employing some 60 percent of the labor force to produce a meager one-third of the national income (McIntire, 1998). On the other hand, the modern large-scale industries sector of Bangladesh, besides its tiny size, suffers from high capital intensity, low and unstable growth and productive inefficiencies (Ahmed, 2001). Although many small firms have been developed over the years in many developing countries (Mann et al., 1989), but in most of the cases the institutions responsible to support the SMEs failed to reach and assisted a fairly small number of firms, leaving a vast majority of the firms' untouched (Farbman and Steel, 1992).

Over and above, Bangladesh has approximately 27,000 medium-sized enterprises and 150,000 small-sized enterprises (defined by the government of Bangladesh as registered enterprises). SMEs account for about 82 percent of the total industrial workforce and 23 percent of the total workforce equivalent to 5 million people. Bangladesh lack sufficient liquidity to invest in heady industries, but has huge number of cheap laborer which made the SME sector very urgent and promising sector for Bangladesh. Trading based SMEs face less problems in comparison to the manufacture based SMEs. Trading has limited risks and ensures the return of 
the capital within short span of time. Therefore, in Bangladesh majority of the business people like to be involved in trading than manufacturing. But the manufacturing sector can create sustainable jobs at a faster rate than the population growth; promote competition and lower prices, supply vital agricultural inputs, and process primary agricultural products. Every year many small firms are established in Bangladesh, though unfortunately many of them disappear abandoning the potential role they could have played in economic development. To combat this undesirable failure and to accelerate rapid growth, it is necessary to understand clearly the problems faced by the manufacture based SME sector. This study thus aimed to explore the major constraints of manufacture based SME development in Bangladesh.

\section{Definition of Small and Medium Enterprise}

Across the world, the SMEs are defined on the basis of two criteria: volume of turnover and number of person employed in a particular organization. Small firms are comprised of wide variety of firms ranging from the single proprietor business, independent business owners who employ a handful of workers. European Commission has defined SME sector as the businesses with fewer than 500 employees, and broken that definition down into three subcategories namely micro-enterprise with between 1 to 9 employees, smallenterprises with between 10 to 99 employees and Medium-enterprises with between 100 to 499 employees. On the other hand, the central bank of Bangladesh defines any business having a "Net-Worth" of up-to Tk. 10 Million or number of employees between 10 to 50 persons as small and business having a "Net-Worth" between Tk. 10 to 100 Million, or employees between 50 to 100 persons as Medium enterprises.

\section{Constraints of Small and Medium Enterprise Development}

Historically, Bangladesh followed a development strategy in which private investment was controlled through a host of regulations involving investment sanctioning, credit disbursement, import licensing, foreign exchange allocation etc,. While these regulatory barriers threaten private investment in general, the impact fell unevenly on SMEs. This was because of the relative inability of the SMEs to cope with the regulations compared to their large-scale counterparts. Thus, the policy regime was largely biased against the SMEs although, paradoxically, promoting SME development was a stated objective of successive governments. The creation and development of SMEs is seen as an important element of overall economic policy, especially for promoting employment, reducing poverty and enhancing overall growth. Arguably, when faced with as many odds as Bangladesh encounters, the development options available to her are limited and hence development of a strong, dynamic and vibrant SME sector is not a luxury but it is rather a dire necessity. Though efficient and productive agriculture is a precondition for rapid sustainable growth, agriculture is unlikely to be engine of growth in future. As the economy already faces huge challenge to absorb some two million people entering the labor force annually, on top of the large number of existing unemployed (Asian Development Outlook 2002), exports and job oriented manufacturing, especially in the SME sector must hold the key to national development over the next quarter century or so (World Bank, 1998).

Razzaque (2003) argued that the factors that are acting as constraints in case of SME market development are: quality and standards, marketing, investment and working capital, shortage of skilled workers, lack of entrepreneurship and management skills, physical infrastructure, transport costs, trade policy and incentives, information, legal and regulatory framework, domestic environment etc. Ahmed (2004) argued that it is necessary to review the Government's industrial policy and technology policy to outline the Government's measures to support SMEs in technological up gradation. Bari, Hema and Haque (2005) have shown some similar issues in case of Pakistani SME sector, those are: inadequate infrastructure, financial barriers and disincentives, adverse government policies, shortage of skilled personnel, technological constraints and lack of innovation and entrepreneurial handicap. Hubner (2000) has pointed out that in case of United States, entrepreneurship development and competitive environment generated through the presence of strong SMEs are quoted to be the leading factors behind the country's recent success in the rivalry against Europe and Japan.

Analysis indicates three important cases within the American success story:

a) Big companies, such as General Electric, adapted/reengineered themselves, became leaner-with the sales and profit rising sharply. 
b) New, small high-tech start-ups have been expanding from traditional industrial sectors to internet based and e-commerce (Amazon.com, Netscape, AOL, e-Bay etc.)

c) Thousands of new, micro and small firms have been founded, many by women, minorities and immigrants.

\section{Methods of the Study}

This is a survey based study. The population of the study is the manufacture based SMEs of Bangladesh. Among seven, two divisional headquarters of Bangladesh namely Khulna (area 1) and Rajshahi (area 2) were chosen respectively as working population of the study. The main logic behind choosing these two cities is that though these two cities are ranked as third and fourth largest cities of Bangladesh, but both the cities are lagging behind in respect of manufacturing based SME development. Moreover, Khulna once was developed in various manufacturing activities but it has lost its fame now and a significant number of factories are either closed or running at a very mediocre rate. Rajshahi, whereas is underdeveloped in all sorts of manufacturing activities from the very beginning. Simple random sampling technique was used to select the SMEs of Khulna and Rajshahi by using two sets of SMEs lists collected from the Bangladesh Small and Cottage Industries Corporation (BSCIC). 51 SME owners/managers from Khulna (area 1) and 23 from Rajshahi (area 2) were interviewed. A set of self administered structured questionnaire was used to collect necessary data required for this study. After administering a series of pretests with exploring several problems associated with manufacture based SMEs, the questionnaire was designed by incorporating 37 problems in four categories namely initial problem (problems associated with establishing the enterprise), operational problem (the problems associated with regular operation), marketing related problems and miscellaneous problems. A 7 point Likert scale was administered in the questionnaire to identify the level of sufferings associated with the above stated problems. Data were being verified and checked after collection and afterwards being entered into a database for necessary analysis.

\section{Results and Discussion}

Table 1: Profiles of the organizations surveyed

\begin{tabular}{|c|c|c|c|c|c|}
\hline Nature of Business & $n=74$ & $\%$ & Number of Present Employees & $n=74$ & $\%$ \\
\hline Food Industries & 23 & 31.1 & Below 5 Persons & 22 & 29.7 \\
\hline Engineering & 19 & 25.1 & 5 to Below 10 Persons & 22 & 29.7 \\
\hline Textile & 4 & 5.4 & 10 and Above Persons & 30 & 40.5 \\
\hline Jute and Allied & 3 & 4.1 & Present Turnover (Annually) & & \\
\hline Animal Food & 2 & 2.7 & Below TK. $1,00,000.00$ & 14 & 23.0 \\
\hline Chemical and Pharmaceuticals & 9 & 12.2 & $\begin{array}{l}\text { TK. } 1,00,000.00 \text { to TK. } \\
5,00,000.00\end{array}$ & 13 & 21.3 \\
\hline Miscellaneous & 14 & 18.9 & Above TK. 5,00,000.00 & 34 & 55.7 \\
\hline Date of Incorporation & & & Missing & 13 & \\
\hline Before 1990 & 31 & 41.9 & Duration of the Business & & \\
\hline 1990 to 2000 & 19 & 25.7 & Within 1Year & 4 & 5.4 \\
\hline 2000 and afterwards & 24 & 32.4 & 1 to 3 Years & 8 & 10.8 \\
\hline Initial Investments & & & More than 3 Years & 62 & 83.8 \\
\hline Below TK. 1,00,000.00 & 18 & 24.3 & Legal Formation & & \\
\hline $\begin{array}{l}\text { TK. } 1,00,000.00 \text { to TK. } \\
5,00,000.00\end{array}$ & 19 & 25.7 & Limited Company & 6 & 8.1 \\
\hline Above TK. 5,00,000.00 & 37 & 50.0 & Sole Trader & 56 & 75.7 \\
\hline Number of Initial Employees & & & Partnership & 12 & 16.2 \\
\hline Below 5 Persons & 26 & 35.1 & Way of starting the Business & & \\
\hline 5 to Below 10 Persons & 21 & 28.4 & Self/With Partners & 50 & 67.6 \\
\hline 10 and Above Persons & 27 & 36.5 & $\begin{array}{l}\text { Bought Going Concern } \\
\text { Inherited }\end{array}$ & $\begin{array}{c}15 \\
9\end{array}$ & $\begin{array}{l}20.3 \\
12.2\end{array}$ \\
\hline
\end{tabular}

All together, 74 owners/managers of SMEs were interviewed. Among them, 23 were from food industries, 19 from light engineering, 4 from textile, 3 from jute and allied, 2 from animal food, 9 from chemical and 
pharmaceuticals and 14 are from other various types of industries. Slightly over 75 percent are of sole proprietorship, 16 percent are partnership and the rest 8 percent are limited companies. 42 percent SMEs have started their business before 1990, about 26 percent have started their business in between 1990 to 2000 and slightly above 32 percent have started their business after 2000. The initial investment of the 50 percent of the SME was above TK. 500,000.00, about 26 percent invested in between 100,000.00 to $500,000.00$ and the remaining 24 percent invested below TK. 100,000.00. About 36 percent of the SMEs have started their business with 10 or more number of employees, 28 percent in between 5 to 10 and the remaining 35 percent less than 5 employees. Whereas at present, more than 40 percent have 10 or more employees and 30 percent with 5 to 10 employees and 30 percent below 5 employees. About 56 percent of the SMEs earn above TK. 5,00,000.00 a year, 21 percent earn in between TK. 1,00,000.00 to TK. 5,00,000.00 and the rest 23 percent earn below TK. 1,00,000.00 a year. About 84 percent of the SMEs are in business for more than 3 years. The rest of the businesses have the duration less than 3 years. It should be noted that about 67 percent of SME owners started their businesses either by their own or with partners, 20 percent of SME owners have bought any ongoing concern. Rest 9 percent have inherited the business.

\section{Table 2: Area wise difference in perceptions among various issues relevant to SME constraints}

\begin{tabular}{llcccc}
\hline SL & Variables & Area & n & Mean & $\begin{array}{c}\text { Std. } \\
\text { Deviation }\end{array}$ \\
\hline 1 & Excessive documentation and lengthy procedures was & 1 & 51 & 3.90 & 2.110 \\
& required for loan application. & 2 & 23 & 4.78 & 2.022 \\
2 & Lack of proper information (e.g., suppliers) to import the & 1 & 51 & 2.78 & 1.653 \\
& right form of main machinery was a problem. & 2 & 23 & 4.30 & 1.917 \\
3 & Tax, Vat payment related bureaucracy and bribery creates & 1 & 51 & 3.78 & 1.963 \\
& problem. & 2 & 23 & 5.22 & 1.565 \\
4 & Distribution network is not efficient (so that it increases cost & 1 & 51 & 3.37 & 1.811 \\
& as well as decreases quality). & 2 & 23 & 4.70 & 1.869 \\
5 & Exploitation from the middlemen is a constant problem. & 1 & 51 & 3.02 & 1.816 \\
& & 2 & 23 & 4.22 & 2.044 \\
6 & Buyers' consciousness regarding the product ingredients and & 1 & 51 & 3.16 & 1.748 \\
& cost of production is absent. & 2 & 23 & 4.13 & 1.842 \\
7 & Lack of trade fair, exhibitions, symposiums, seminars, & 1 & 51 & 3.41 & 2.109 \\
\multirow{2}{*}{8} & workshops hinders the development of business. & 2 & 23 & 4.35 & 1.496 \\
& Absence of adequate IT facilities (internet, e-commerce, and & 1 & 51 & 3.31 & 2.186 \\
& e-business) also hinders these business growths. & 2 & 23 & 4.91 & .996 \\
\hline
\end{tabular}

In table number, 2 some 8 issues have been identified among the 37 problems in which the perceptions are different among the two major cities namely Khulna (area 1) and Rajshahi (area 2). The researchers tried to establish the logic behind the difference of opinion of the entrepreneurs of the two cities. It can be noted here that though now-a-days Khulna does not have that fame and business practice but still it is called industrial city and it has a long tradition in manufacturing sector. On the contrary, Rajshahi is lagging far behind in respect of industrial sector. Very few entrepreneurial activities can be seen here.

Documentation: The most representative characteristic of smaller firms, and the greatest difference between them and larger firms, is their greater information capacity (Berger and Udell, 1998). The study also shows that entrepreneurs faced problems due to excessive document requirements during registration as well as during borrowings. The study also identified that the entrepreneurs of two cities differ in case of documentation. The reason may be that in Khulna the bankers, registration authority as well as borrower are used to the documentation practices whereas in Rajshahi being new in this sector, the entrepreneurs are not yet used to this system and thus suffer more.

Information: The biggest problem faced by the small firm is that they do not have the access to all information required to develop new product, or to understand the market and to find out the most feasible solution of the problems faced by the customers. The reason is that they do not have enough financial strength to carry out all those activities, research etc. (Sagar and Zwaan, 2006). Here in this study, it can be noted that lack of information is an acute constraint in Rajshahi. However, this problem is not that prominent 
in Khulna. As it has been stated earlier that Khulna has more exposure than Rajshahi and thus entrepreneurs have more access to information.

Tax, Vat payment: Fiscal measures, such as tax deductions for investments at national level, could also facilitate the uptake of specific measures by micro and small businesses (De Jong and Vermeulen, 2006). This study also supports the statement as it has been identified that tax and vat related beaucracy and bribery create problems for small business both in Khulna and Rajshahi. But the entrepreneurs of Rajshahi thinks that the burden is too much. The reason may be that the entrepreneurs at Rajshahi are comparatively less experienced than Khulna. It is the task of the government to protect the small and medium scale firm during their period of progress as well as consolidation. Infant industry argument also supports that ideology. Without the assistance, it is very hard for them to survive and face the stiff challenge from the comparatively larger, and MNC's (Lorenzoni and Lipparini, 1999).

Distribution network: Distribution is a process in which, an organization or set of organizations (gobetweens) involved in the process of making a product or service available for use or consumption by a consumer or business user. For a business owner, goal-oriented behaviors between the business and other entities, such as suppliers and customers, can be conceived of as strategic actions (Teruel and MartinezSolano, 2007). Both at Khulna and Rajshahi, this problem of distribution network is evident. But as the business practice is much high in Khulna the entrepreneurs are more acquainted with the system and thus suffer less. In much the same way that the organizations own sales and distribution activities need to be monitored and managed. In practice, many organizations use a mix of different channels; in particular, they may complement a direct sales force, calling on the larger accounts, with agents, covering the smaller customers and prospects. The case is not quite the same for small and medium scale firm. They frequently suffer from fund scarcity in maintaining and carrying distribution channel (Teruel and Martínez-Solano, 2007).

Exploitation by the Middlemen: Middlemen play the major role in transferring products from the manufacturer to the end user. Middlemen expand the capacity of the manufacturer to distribute products to the end user, transfer title between channel levels and communicate product information to all channel participants. When the financial and expert resources are available in-house, manufacturers can increase their profit margins by reducing the involvement of middlemen. Middlemen in normal case make the task easier for both seller and consumer; however they sometime become and act as enigma for small business operators (Pihkala et al., 1999). It has been observed that middlemen are always threat especially for the small business owners. Any type of bondage or ties in between the similar types of SMEs may reduce the extent of the problem. The survey result of this study show that SMEs have problems with middlemen as they perceive them as exploiter of the small entities like most of the SMEs whereas this problem is more in Rajshahi than Khulna.

Buyers' consciousness

The success of a firm's operations may be influenced by many factors, including the level to which the firm is perceived to offer value, high quality, trust and minimal risk in its relationship with consumers (Begley et al., 1996). The mandatory task of each and every business organization is to create awareness and therefore brand loyalty among its group of customers. Along with product competency, communication competencies are also essential to serve that purpose (Neergaard, 2005). Buyer's consciousness building is never an easy task especially in this turbulent and hyper competitive business environment. Brand positioning is even more difficult than capturing new customer. Smaller firms life always tested in this regard as they seldom possesses the capacity to go for building strong buyers consciousness about their products and offerings (Titman and Wessels, 1988). The study also shows that absence of buyers' consciousness is a problem for the SMEs especially for those who are situated in Rajshahi and at the same time the SMEs don't have any activity to make the customers aware. Hence, the buyers often intend to buy foreign goods which cause problems for the local SMEs.

Trade fair, exhibitions, symposiums: Business events, trade fairs and trade shows are an integral part of business life style. Once, these trade shows were generally based on industrial goods or was meant basically for the business class. Now-a-days, the biggest trade shows are organized for the common public, specifically 
the middle income group and more towards household groups (Pihkala et al., 1999). Many trade shows are organized to encourage the locals as well as the multinational companies to participate and see the response of the market towards their products. Consumers can have a direct interface with the new and cheap products in the markets and can also enjoy purchasing and browsing through the new products in the market. However, it is difficult for the smaller firm to arrange such programs. One thing they can do by arranging it with collaborative efforts (Park, 2005). Most of these trade shows always present a favorable place for both the consumers and the companies. These trade shows and fairs are one of the best ways to explore, expand and learn about the new business strategies and market conditions (Park, 2005). It has been a constant complain that Bangladeshi Embassies in various countries don't perform as they are supposed to. Despite importance of organizing these events, the study shows that Bangladesh lags behind in organizing and participating in various trade fares exhibitions, and/or symposiums and thus fails to achieve proper foreign attention. The survey results also support this issue as such the entrepreneurs of area 1 have realized this problem less than the entrepreneurs of area 2 as they are much involved with arranging and participating in trade fares and exhibitions.

Adequate IT facilities: Small businesses typically focus on researching, understanding and managing elements related to their businesses. Few, if any, have time to monitor the daily changes that impact information technology. Even fewer possess the resources necessary to keep current with changes to Microsoft Windows, Microsoft Office, and proprietary business software, critical business applications, printing technologies, web-based tools, email services and a myriad of other technology concerns. Small businesses can avoid and overcome these issues by developing a service relationship with a qualified information technology partner (Hoffman et al., 1998). Internet connectivity plays important role in updating the manufacturers with the latest technology, product design, and customer choice. Small entrepreneurs especially those who are located in remote places still are not connected with internet. Thus SMEs, both at Khulna and Rajshahi agreed that absence of IT facilities hinders their growth whereas the entrepreneurs of Rajshahi have faced the problem more than those of Khulna.

Table 3: Ten Major Constraints of Manufacture based SMEs in Bangladesh

\begin{tabular}{|c|c|c|c|c|c|}
\hline SL. & Variables & $n$ & Mean & $\begin{array}{l}\text { Std. } \\
\text { Dev. }\end{array}$ & $\begin{array}{l}\text { Std. Error } \\
\text { Mean }\end{array}$ \\
\hline 1 & $\begin{array}{l}\text { No electricity/water or inconsistency of supply of } \\
\text { electricity/ water is a problem. }\end{array}$ & 74 & 6.01 & 1.692 & 0.197 \\
\hline 2 & $\begin{array}{l}\text { Fluctuation in price of raw materials is a constant } \\
\text { threat. }\end{array}$ & 74 & 5.66 & 1.529 & 0.178 \\
\hline 3 & $\begin{array}{l}\text { Political unrest (leading to frequent hartals, strikes,) } \\
\text { create obstacle for business. }\end{array}$ & 74 & 5.46 & 1.946 & 0.226 \\
\hline 4 & High interest rate of borrowing is a major constraint. & 74 & 5.24 & 1.797 & 0.209 \\
\hline 5 & $\begin{array}{l}\text { High transportation cost increases the total cost and } \\
\text { thus create problem. }\end{array}$ & 74 & 4.76 & 1.678 & 0.195 \\
\hline 6 & $\begin{array}{l}\text { Financing (working capital) is still a major problem to } \\
\text { run/expand the business. }\end{array}$ & 74 & 4.65 & 1.771 & 0.206 \\
\hline 7 & $\begin{array}{l}\text { Inadequate/ inconsistent supply of raw materials is a } \\
\text { problem. }\end{array}$ & 74 & 4.61 & 1.879 & 0.218 \\
\hline 8 & $\begin{array}{l}\text { Financing was a major problem while establishing the } \\
\text { business. }\end{array}$ & 74 & 4.58 & 1.952 & 0.227 \\
\hline 9 & $\begin{array}{l}\text { Inadequate or no support for exporting the goods to } \\
\text { other countries. }\end{array}$ & 74 & 4.38 & 1.914 & 0.222 \\
\hline 10 & $\begin{array}{l}\text { Inadequate social infrastructure for smooth marketing } \\
\text { throughout the country. }\end{array}$ & 74 & 4.28 & 1.676 & 0.195 \\
\hline
\end{tabular}

The survey collects organizations perceptions on the problems stated in the questionnaire. After screening the perceptions of 74 organizations regarding the problems they are facing, 10 among 37 have been identified as major problems faced by most of the organizations. Thus the study considers those 10 problems in order of 
ranking and administers further analysis. Understanding the nature of the problem, should help practitioners to overcome the constraints.

Small business success has social as well as economic consequences for communities and geographic regions. Business success in developing new products and ways of doing business adds value to the economy and improves the quality of life in communities (Dabson, 2001).

Supply of electricity and/or water: The study result shows that the business owners are facing immense problem as far as supply of water and electricity are concerned in their respective areas. The previous research also supports the findings. Raynor and Weinberg (2004) mentioned that Small business owners normally seeks assistance from the authority for providing uninterrupted energy supply, however normally seldom they get it according to their requirement. Bangladesh suffers generation and electricity problem from the very early of its independence. As days go on, the demand of electricity is also increasing. Though the production of electricity has increased, but still lags far behind than the demand. Supply of water, on the other hand, is not smooth allover the country. Few decades ago, the country was effluent in water supply as plenty of rivers were flowing. Dam on Padma and many other rivers on the upstream has caused tremendous problem in the supply of water. This has crippled not only in the supply of water, but also in electric generation as the only hydro-electricity can't operate fully due to lack of water supply.

Raw materials: The outcome of the survey of this particular research is signifying the fact that the small business owners of the covered areas are facing constant threat regarding the price fluctuation as well as the scarcity of raw materials. Small businesses commonly faced basket of problems in acquiring cheap raw materials. Their capacity is less and therefore they are most vulnerable to the corresponding changes of market forces like price, demand, supply etc. (Newbery and Green, 1996). Bangladesh is a small country and the majority of the population is dependent on agriculture. Moreover very few mineral sources are available in this country. Though natural gas and coalmine is being extracted for quite a long time but lack of technical know-how has made the government dependant to other country. Therefore, besides agricultural products, most of the raw materials are being imported by the government which increases the price of most of the raw materials.

Political unrest: The study shows that the political unrests (leading to frequent hartals, strikes, blockage etc.) create obstacle for business. Score 5.46 expresses the message that the political unrest in Bangladesh is a serious hindrance in creating, developing and sustaining the small and medium enterprises. Asheim (1994) also indicated the same as he mentioned that instable government seldom succeeds in stimulating entrepreneurship. Instability hinder economic activities and therefore, entrepreneurial activities and in broader sense the economic growth of a country. Though Bangladesh has glorious democratic background, it has many black sides in respect of undemocratic government. Moreover, inefficiency and corruption of the government officials, lack of responsible behavior of the opposition often lead to political unrest and thus creates huge problem for the manufacturing sector.

Interest rate of borrowing: The SMEs face intense problem and they have to go for funding at relatively higher interest rate, afterwards which becomes the enigma against their existence. Commercial banks of the underdeveloped countries normally do not incline to give loans to the small business owner; the picture is not quite the same in case of the comparatively larger firms. It is quite often noticed that a small enterprise reach towards the end only due to unavailability of funds irrespective of its potentiality (Fillis, 2004). In addition to ensuring that the business has enough capital, the small business owner must also be mindful of contribution margin (sales minus variable costs). To obtain breakeven, the business must be able to reach a level of sales where the contribution margin equals fixed costs. When they first start out, many small business owners under price their products to a point where even at their maximum capacity, it would be impossible to reach break even level. Cost controls or price increases often resolve this problem (Berger and Udell, 1998). Furthermore, in calculating and determining the right mix of cost and revenue the calculation of the borrowing rate is a significant force (Walsh and Newbert, 2002).

Transportation cost: Transport and mobility is the component that holds everything together. Domestic transportation normally takes place using a single document: the bill of lading, the contract of carriage 
between the shipper and carrier (Johannisson, 1986). Transportation competencies always remain as a test of character for smaller firms as their boundary is congested and therefore it is a challenge for them to expand from that with limited transportation resources and available fund (Lumpkin et al., 2001). Bangladesh is plethora in rivers, thousands of bridge is required for road and railway communication but it is yet to construct all the required bridges. Moreover, due of lack of sufficient water, the river communication has also been reduced to a major extent. Therefore, fast and cheap transportation is not yet available and thus manufactures' problem is quite significant in respect of transporting their raw materials as well as finished goods.

Financing: Small business capital provides the money that the business needs to operate and function on a daily basis. There are a variety of ways business can obtain small business capital. However, most lenders will not finance small business without any credit history. This means that small business owners need to separate personal credit from business credit. Small businesses often face a variety of problems related to their size. A frequent cause of bankruptcy is undercapitalization. This is often a result of poor planning rather than economic conditions (Browning et al., 2006). The survey result also implies that the problem is rooted and it is quite significant especially in the financing cases of the SMEs.

It is argued that the states should set up national programs to finance and/or co-finance technological improvements, the implementation of internal environmental and energy policies and the employment of experts in eco and energy efficiency by micro and small businesses.

Support for exporting: Exporting goods are never easy for the firms of third world countries. The situation is even worse from the perspective of the smaller firms. It is almost impossible for them to think about exporting without intense assistance from the govt. In general, an export movement can be handled by the operator in several ways. Each option requires a different degree of shipper and/or intermediary involvement. Exporting goods beyond the boundary of the country takes lot of effort and quality products or product after proper quality testing service is essential for that regard (Rip and Kemp, 1998). This study indicates relatively lesser significant problem of exporting for the small business. The reason may be that most of small businesses are yet to achieve the strength and confidence for exporting.

Social infrastructure for smooth marketing: Small business owners in comparatively underdeveloped region find a huge amount of complexities in following the modern value delivery system (Bevan and Danbol, 2002). Nevertheless, smaller firm most often, have not been able to operate in smooth marketing condition in developing countries. Their tasks are critical as well as risky and based on fate rather than on their own performance (Walker and Brown, 2004). Here, the study indicates that social infrastructure is a problem for them though relatively at the lower extreme. This is also because of the fact that the operator of small businesses in the country seldom think about marketing. Their major thinking normally concentrates on surviving.

\section{Conclusion and Recommendations}

This study aimed to explore the constraints for the development of manufacture based SMEs in Bangladesh. Two divisional cities of Bangladesh namely Khulna (area 1) and Rajshahi (area 2) have been considered as case point. The study reveals that except few cases, SMEs of both regions suffer a lot in many ways that ultimately hinder their growth and development. Among others, the main constraints are lack of access to utility facilities like electricity, water and gas (where applicable), frequent changes of the prices of raw materials as well as shortage of raw materials, political unrest, high interest rate on borrowings, insufficient and high transportation cost, lack of adequate financing for ongoing concern, and inadequate infrastructure which includes registration, tax \& VAT collection, advice and monitoring by the government. Despite several constraints, the researchers believe that there are ways to overcome the constraints.

Supply of electricity, water and gas (where applicable) is the prime consideration for any sorts of industrial development. Government of Bangladesh has addressed this issue as one of the most important agenda to implement. It must have to expedite not only to help establishing the new manufacturing farms but also to support the existing firms. Construction of bridges requires time as well as huge investment. Government will 
not be able to construct all the required bridges in short span of time due to lack of fund. Government should recover the lands of all the rivers and cannels and dig where necessary in order to restore the water transportation. Recovering the lands of the rivers and cannels and digging them not only help to enhance water communication system it will also help in increasing the supply of water to both industry as well as cultivation lands. Bank interest rate must have to be curtailed to a greater extent to reduce the operation cost for all sorts of production activities. Moreover, import duties has to be reduced in some selected industries where the firms are relatively new and small in entity until they become strong enough to compete with foreign firms. Last not the least, there must have to be a clam and friendly environment in respect of political and good governance to support all sorts of business activities.

\section{Future Research}

A separate and more detailed study can be taken through out Bangladesh to find out the similarities and dissimilarities regarding the constraints of manufacture based SMEs. The other parties of SME like Banks, Government organizations like BSCIC can be incorporated for proper evaluation of the problem. Then, proper measures can be suggested based on the necessity of particular regions.

\section{References}

Ahmed, M. U. (1987). Entrepreneurship Development with Some Reference to Bangladesh. In Mannan, A. (eds.), Entrepreneurship and Management in Bangladesh, Chittagong, Bangladesh.

Ahmed, M. U. (2001). Development Potentials of Micro-enterprises in Bangladesh: An Analysis of Issues and Constraints. Bangladesh Journal of Political Economy, 15 (1): 141-174.

Ahmed, M. U. (2004). Promoting Business and Technological Incubation for Improved Competitiveness of Small and Medium-sized Industries through Application of Modern and Efficient Technologies in Bangladesh. Paper presented at General Economics Division, Planning Commission, Dhaka, Bangladesh.

Anderson, D. (1982). Small Industries in Development Countries: A Discussion of Issues. World Development, 10 (11): 913-948.

Asheim, B. (1994). Industrial Districts Inter-Firm Co-operation and Endogenous Technological Development: The Experience of Developed Countries. In (eds.), Technical Dynamism in Industrial Districts: An Alternative Approach to Industrialization in Developing Countries. NY: UN, 92-129.

Bari, F., Hema, A. and Haque, E. U. (2005). SME Development in Pakistan: Analyzing the Constraints to Growth. Pakistan Resident Mission Working Paper, 3.

Begley, J., Ming, J. and Watts, S. (1996). Bankruptcy Classification Errors in the 1980s: An Empirical Analysis of Altman's and Ohlson's Models. Accounting Studies, 1(4): 267-284.

Berger, A. N. and Udell, G. F. (1998). The Economics of Small Business Finance: The Roles of Private Equity and Debt Markets in the Financial Growth Cycle. Journal of Banking and Finance, 22(6): 613-673.

Bevan, A. A. and Danbolt, J. (2002). Capital Structure and Its Determinants in the UK: A De-compositional Analysis. Applied Financial Economics, 12(3): 159-170.

Birch, D. L. (1979). The Job Generation Process. MIT Program on Neighborhood and Regional Change, Cambridge, Mass: MIT.

Browning, L.D., Beyer, J. M. and Sheltler, J. C. (2006). Building Cooperation in a Competitive Industry: SEMATECH and the Semiconductor Industry. Academy of Management, 38(1): 113-151.

Dabson, B. (2001). Supporting Rural Entrepreneurship. In (eds.), Exploring Policy Options for a New Rural America, Kansas City. MO: Federal Reserve Bank of Kansas City, 35-47.

De Jong, J. P. J. and Vermeulen, P. A. M. (2006). Determinants of Product Innovation in Small Firms: A Comparison across Industries. International Small Business Journal, 24(6): 587-609.

Farbman, M., and W, F., Steel (1992).Research Issues for Small Enterprise Development. Journal of Small Enterprise Development, 3(2): 26-34.

Fillis, I. (2004). The Internationalizing Smaller Craft Firm: Insights from the Marketing/ Entrepreneurship Interface. International Small Business Journal, 22(1): 57-82.

Gibb, A. A. (1993). Small Business Development in Central and Eastern Europe-Opportunity for Rethink. Journal of Business Venturing, 8: 461-486. 
Hoffman, K., Parejo, M., Bessant, J. and Perren, L. (1998). Small Firms, R\&D, Technology and Innovation in the UK: A Literature Review. Technovation, 18(1): 39-55.

Hubner, W. (2000). SME development in countries of Central Asia: Constraints, cultural aspects, and role of international assistance. United Nations Industrial Development Organization (UNIDO), Vienna.

Johannisson, B. (1986). Network Strategies: Management Technology for Entrepreneurship and Change. International Small Business Journal, 1: 19-30.

Lorenzoni, G. and Lipparini, A. (1999). The Leveraging of Interfirm Relationships as a Distinctive Organizational Capability: A Longitudinal Study. Strategic Management Journal, 20(4): 317-338.

Lumpkin, G. T., Hills, G. E. and Shrader, R. C. (2001). Opportunity Recognition, Chicago, IL: University of Illinois.

Mann, C. K., Grindle, M. S. and Shipton, P. (1989). Seeking Solutions Framework and Cases for Small Enterprise Development Programs. HIID Connecticut: Kurmanina Press.

McIntire, J. (1998). The Prospects for Agricultural Growth. In Faruqee, R. (eds.), Bangladesh Agriculture in the 21th Century, Dhaka University Press Ltd.

Neergaard, H. (2005). Networking Activities in Technology-based Entrepreneurial Teams. International Small Business Journal, 23(3): 257-258.

Newbery, D. M. and Green, R. (1996). Regulation, Public Ownership and Privatization of the English Electricity Industry. In Gilbert, R.J. and Kahn, E.P. (eds.), International Comparisons of Electricity Regulation, New York: Cambridge University Press, 25-81.

Park, J. S. (2005). Towards a Model of Opportunity Recognition and Development. In During, R. and Kauser, S. (eds.), New Technology-Based Firms in the New Millennium, Oxford: Elsevier, 63-80.

Pihkala, T., Varamäki, E. and Vesalainen, J. (1999). Virtual Organization and the SMEs: A Review and Model Development. Entrepreneurship and Regional Development, 11(4): 335-350.

Raynor, M. E. and Weinberg, H. S. (2004). Beyond Segmentation. Marketing Management, 13(6): 22-28.

Razzaque, A., (2003). Market Development for Bangladesh's SMEs: An Analysis of Issues and Constraints. Paper presented at Bangladesh Enterprise Institute, Dhaka.

Rip, A. and Kemp, R. (1998). Technological Change. In Rayner, S. and Malone, E.L. (eds.), Human Choice and Climate Change, Columbus, $\mathrm{OH}$ : Battelle Press.

Sagar, A. D. and Van der Zwaan, B. (2006). Technological Innovation in the Energy Sector: R\&D, Deployment, and Learning-by-doing. Energy Policy, 34(17): 2601-2608.

Sarder, J. H. (1990). Potentiality of Small Scale Industries in Bangladesh. The Dhaka University Studies, 11 (c): 191-202.

Teruel T., and Martínez-Solano J. (2007). Virtual Organization and the SMEs: a Review and Model Development. Entrepreneurship and Regional Development 11(4): 335-50.

The World Bank and Bangladesh Centre for Advanced Studies (1998). Bangladesh 2020: A long-run Perspective, 20-26.

Titman, S. and Wessels, R. (1988). The Determinants of Capital Structure Choice. Journal of Finance, 43(1): 119.

Walker, E. and Brown, A. (2004): What Success Factors are Important to Small Business Owners. International Small Business Journal, 22(6): 577-594.

Walsh, S. T., Kirchhoff, B. A. and Newbert, S. (2002). Differentiating Market Strategies for Disruptive Technologies. Transactions on Engineering Management, 49(4): 341-351. 